\title{
Eksistensi Hukum Adat Daerah dalam Sebambangan Yang Berkaitan Dengan Peranan Undang-Undang Nomor 1 Tahun 1974 Tentang Perkawinan Berdasarkan Hukum Perdata Nasional
}

\author{
Angga Alfiyan', Aprinisa ${ }^{2}$, Okta Ainita ${ }^{3}$ \\ FAKULTAS HUKUM UNIVERSITAS BANDAR LAMPUNG \\ Jalan Zainal Abidin Pagar Alam. No 26, Labuhan Ratu, Bandar Lampung \\ Email : \\ Angga.alfian@ubl.ac.id; aprinisa@ubl.ac.id; okta.anita@ubl.ac.id
}

\begin{abstract}
Abstrak
Masyarakat Indonesia masih terdapat berbagai macam tradisi yang masih dilakukan dengan baik maupun telah hilang. Tradisi-tradisi tersebut mengandung nilai-nilai budaya dan moral yang memiliki tujuan baik untuk menciptakan masyarakat yang berakhlak baik dan berperadaban, Penelitian ini menggunakan metode penelitian yuridis normatif, yaitu penelitian dilakukan terhadap peraturan perundang-undangan dan norma-norma positif dalam sistem perundang-undangan yang berkaitan dengan permasalahan penulisan ini, Akibat hukum dari perkawinan antara suami istri menurut Undang-Undang Nomor 1 Tahun 1974 tentang Perkawinan, telah diatur dengan jelas dan gampang dipahami, ketika adanya niat yang baik dalam menegakkan dan menghormati Undang-Undang. Suatu perkawinan yang dilangsungkan secara sah menurut hukum akan menimbulkan berbagai akibat hukum, yang pada pokoknya ada tiga hal penting yang perlu diperhatikan, yaitu : Hubungan antara suami istri, Hubungan orang tua dengan anak sebagai ahli waris dan dengan kekerabatannya, Hubungan anak-anak dengan kedua orang tuannya dan dengan kerabat ayah ibuny. Salah satu materi hukum adat asli yang dimasukkan dalam Undang-Undang perkawinan adalah pengaturan hukum harta perkawinan. Penyelesaian prodan kontra dalam masyarakat dilakukan secara kekeluargaan dan secara adat. Beda halnya kalau ada paksaan," terang Rusdi, Juma. Dalam adat Lampung, Rusdi mengatakan, memang berlaku adat kawin lari yang telah berlangsung secara turun-temurun. "Tapi kembali lagi ke tata cara itu. Ada syarat-syarat tertentu yang harus dipenuhi. Misalnya ada uang tali pengendur dan surat tenepik," dan pembayaran uang jujur yang menjadi salah satu syarat sebambangan dalam adat Lampung.

Kata Kunci : $\underline{\text { Hukum Adat, Daerah, Sebambangan, Perkawinan }}$
\end{abstract}




\section{Latar Belakang}

Pada Masyarakat Indonesia masih terdapat berbagai macam tradisi yang masih dilakukan dengan baik maupun telah hilang. Tradisi-tradisi tersebut mengandung nilai-nilai budaya dan moral yang memiliki tujuan baik untuk menciptakan masyarakat yang berakhlak baik dan berperadaban. Masyarakat adalah sekumpulan manusia yang saling berinteraksi serta memiliki suatu ikatan yang kuat karena memiliki latar belakang yang sama, mempunyai ikatan batin yang sama antara mereka serta tata cara dari wewenang dan kejasama antara berbagai kelompok kemudian mempunyai hubungan timbal balik antar mereka. Perkawinan ialah ikatan lahir bathin antara seorang pria dengan seorang wanita sebagai suami isteri dengan tujuan membentuk keluarga (rumah tangga) yang bahagia dan kekal berdasarkan Ketuhanan Yang Maha Esa. ${ }^{1}$ Perkawinan merupakan gerbang terbentuknya keluarga dalam kehidupan masyarakat, bahkan kelangsungan hidup suatu masyarakat dijamin dalam dan oleh perkawinan.. Perkawinan adalah ikatan sosial atau ikatan perjanjian hukum antar pribadi yang membentuk hubungan kekerabatan dan yang merupakan suatu pranata dalam ,

\footnotetext{
${ }^{1}$ Sudarsono, Hukum Perkawinan Nasional, Rineka Cipta, Jakarta, 1991, hlm 9
}

budaya setempat yang meresmikan hubungan antar pribadi yang biasanya intim dan seksual. Perkawinan umumnya dimulai dan diresmikan dengan upacara pernikahan. Umumnya perkawinan dijalani dengan maksud untuk membentuk keluarga. Perkawinan merupakan suatu perjanjian yang diadakan oleh dua orang, dalam hal ini perjanjian antara seorang pria dengan seorang wanita dengan tujuan, membentuk keluarga (rumah tangga) yang bahagia dan kekal berdasarkan Ketuhanan Yang Maha Esa. ${ }^{2}$ Adat perkawinan adalah aturan-aturan hukum adat yang mengatur tentang bentukbentuk perkawinan, caracara pelamaran, upacara perkawinan dan putusnya perkawinan di Indonesia Perkawinanan juga merupakan suatu perbuatan hukum, sehingga konsekuensi bagi setiap perbuatan hukum yang sah adalah menimbulkan akibat hukum, berupa hak dan kewajiban bagi kedua belah pihak suami istri atau juga pihak lain dengan siapa salah satu puhak atau kedua-duanya atau suami istri mengadakan hubungan. Setiap orang atau pasangan (pria dengan wanita) jika sudah melakukan perkawinan maka ada ikatan kewajiban dan hak

\footnotetext{
${ }^{2}$ Soedharyo Soimin, Hukum Orang dan Keluarga Edisi Revisi, Sinar Grafika, 2001, hlm 6
} 
diantara mereka berdua dan anak-anak yang lahir dari perkawinan tersebut.

\section{Permasalahan}

a. Adakah Kaitan Hukum Antara Eksistensi Hukum adat dalam acara sebambangan masyarakat Lampung dengan Undang-Undang Nomor 1 Tahun 1974 Tentang Perkawinan?

b. Bagaimanakah Penyelesaian kontra adat Sebambangan dimata masyarakat Umum yang menjadi Pro dan Kontra?

\section{Metode Penelitian}

Penelitian ini menggunakan metode penelitian yuridis normatif, yaitu penelitian dilakukan terhadap peraturan perundang-undangan dan norma-norma positif dalam sistem perundang-undangan yang berkaitan dengan permasalahan penulisan ini

\section{Pembahasan}

Analisis Kasus :

Kasus kawin lari yang melibatkan remaja putri berusia 14 tahun di Tulangbawang terus menuai pro-kontra. Pemuda berinisial SU (19) dikabarkan melarikan ES (14), siswi kelas IX MTs. Rusdi Rifai, tokoh adat Megou Pak dari Marga Buay Aji, menilai, masalah ini seharusnya diselesaikan secara kekeluargaan. Menurut dia, berdasarkan kronologi yang diperoleh dari Polres Tulangbawang, SU dan ES memang suka sama suka. Apalagi, dari hasil konfirmasi polisi dengan tokoh adat Lampung Megou Pak yang diwakili Buya Herman TB dan Nurhaki, ES bukanlah korban penculikan. Dia menjelaskan, dalam adat Lampung, peristiwa itu merupakan larian. Kawin lari itu juga dianggap sah karena keduanya meninggalkan surat dan uang sebagai "tali pengendur"."Jadi dalam kasus ini kembali lagi kepada ES-nya. Apakah dia larian atas dasar suka sama suka atau memang ada paksaan. Kalau memang atas dasar suka sama suka, baiknya diselesaikan secara kekeluargaan dan secara adat. Beda halnya kalau ada paksaan," terang Rusdi, Jumat, 20 Juli 2018. Dalam adat Lampung, Rusdi mengatakan, memang berlaku adat kawin lari yang telah berlangsung secara turuntemurun. "Tapi kembali lagi ke tata cara itu. Ada syarat-syarat tertentu yang harus dipenuhi. Misalnya ada uang tali pengendur dan surat tenepik," tegasnya. Di lain pihak, Kasatreskrim Polres Tuba AKP Zainul Fachry belum mau berspekulasi untuk mengambil sikap terkait kasus kawin lari ini. "Ke tokoh adat saja. Apa kata mereka," ujar Zainul singkat. Kasus Kawin Lari Mencuat, Kapolres Tuba Beberkan Hukum Adat dan Hukum Positif di Indonesi. Penyidik Satreskrim Polres 
Tuba berkoordinasi dengan tokoh adat Megou Pak terkait kasus kawin lari ES. Laporan Reporter Tribun Lampung Endra Zulkarnain TRIBUNLAMPUNG.CO.ID, TULANGBAWANG -Kapolres

Tulangbawang AKBP Raswanto Hadiwibowo angkat bicara terkait simpang siurnya berita yang menyebut Polres tidak menanggapi laporan penculikan anak di bawah umur. Kapolres mengatakan, informasi yang diberikan oleh pihak keluarga kepada Satuan Reserse Kriminal (Satreskrim) hari Rabu (18/7) siang, bahwa ES (14) siswi kelas IX MTS (madrasah tsanawiyah) telah di culik oleh beberapa orang dengan mengendarai kendaraan roda empat adalah tidak benar. Saat itu pihak keluarga ES yang datang ke Polres, diarahkan ke ruang Satreskrim, karena Kasat Reskrim AKP Zainul Fachry sedang melakukan gelar perkara. Menurut Raswanto, pihak keluarga ES saat itu menunggu sampai usai kegiatan, lalu Kasat Reskrim beserta anggota Satreskrim langsung bertemu dengan pihak keluarga ES dan mendengarkan apa yang sebenarnya terjadi. Setelah mengetahui kejadian yang sebenarnya, Kasat Reskrim langsung berkoordinasi dengan tokoh adat Lampung dan pihak keluarga diminta untuk menunggu. Koordinasi dilakukan untuk menelisik hukum adat yang berlaku dalam budaya orang Lampung terkait kawin lari. Ini juga dilakukan untuk menelisik ada tidaknya unsur pidana penculikan sebagaimana diatur dalam KUHP sebagai hukum positif di Indoesia. "Karena tidak sabar menunggu, pihak keluarga ES yang datang langsung pulang dari Polres. Nah tadi malam, Kasat Reskrim juga langsung melakukan klarifikasi dengan mendatangi rumah SU (19), yang berada di Kampung Kibang Pacing, Kecamatan Menggala," beber Kapolres. Di rumah tersebut, Kasat Reskrim langsung bertemu dengan ES dan pihak keluarga SU. Menurut keterangan langsung dari ES diketahui bahwa yang bersangkutan pada Rabu (18/07) kemarin tidak di culik oleh siapapun. Melainkan datang sendiri ke rumah SU dengan cara berangkat dari sekolahnya di MTs sekitar pukul 09.00 WIB, menumpang sepeda motor milik warga (seorang ibu-ibu). "Tujuan ES datang ke rumah SU adalah berkeinginan untuk dinikahkan dengan SU," terang AKBP Raswanto. Kapolres menambahkan, dua hari sebelumnya pada Senin (16/7) ES telah dijemput oleh SU di rumahnya yang berada di Kampung Dwi Warga Tunggal Jaya, Kecamatan Banjar Agung, untuk diajak larian (menikah) yang telah meninggalkan sepucuk surat dan uang sebesar Rp. 50 Ribu sebagai uang adat.

Hal itu sesuai tata cara budaya kawin lari sebagaimana diatur dalam hukum adat 
orang Lampung yang telah berlangsung secara turun temurun. "Pada malam harinya, pihak dari keluarga ES datang ke rumah SU untuk menjemput ES pulang dan telah terjadi kesepakatan hitam diatas putih, yang mana isi dari kesepakatan tersebut mengatakan, bahwa pihak dari keluarga ES akan menikahkan ES dengan SU setelah ES menamatkan sekolahnya terlebih dahulu," papar Raswanto. Dari hasil konfirmasi pihak Polres dengan Tokoh Adat Lampung Megou Pak yang diwakili Buya Herman TB dan Nurhaki, kejadian yang dialami oleh ES bukan penculikan. Tetapi peristiwa tersebut menurut adat Lampung dinamakan "larian" dan sudah sah karena telah meninggalkan surat dan uang sebagai "tali pengendur". Sistem hukum di indonesia (konstitusi) juga mengakomodir adanya hukum adat, sebagaimana terdapat dalam Pasal 18B ayat 2 Undang-Undang Dasar 1945 yang berbunyi : "Negara mengakui dan menghormati kesatuan-kesatuan masyarakat hukum adat beserta hak-hak tradisionalnya, sepanjang masih hidup dan sesuai dengan perkembangan masyarakat dan Prinsip Negara Kesatuan Republik Indonesia, yang diatur dalam undangundang. Melihat suasana hukum di Indonesia sebagai negara yang kaya akan kebudayaan serta masih mengakui adanya hukum adat pasti memiliki keberagaman hukum adat yang masih dipertahankan dan terus dilestarikan, sebagaimana yang telah dijamin dalam Pasal 32 ayat (1) UUD 1945 bahwa negara memajukan kebudayaan nasional Indonesia di tengah peradaban dunia dengan menjamin kebebasan masyarakat dalam memelihara dan mengembangkan nilai-nilai budayanya, maka masih terdapat masyarakat adat yang mempertahankan budaya atau hukumnya dalam segala aspek kehidupan termasuk pengaturan tentang hukum perkawinan. Setiap suku memiliki hukum adat perkawinan yang berbeda sesuai dengan ciri khas daerah dan sejarahnya masing-masing. Misalnya Suku Jawa, Papua, dan Batak yang memiliki tata cara atau hukum adat tersendiri dalam melaksanakan perkawinan, begitu pula dengan masyarakat adat Lampung. Masyarakat adat Lampung ini dikategorikan ke dalam masyarakat hukum genealogis, yaitu suatu kesatuan masyarakat yang teratur, dimana para anggotanya terikat pada suatu garis keturunan yang sama dari satu leluhur, baik secara langsung karena hubungan darah (keturunan) atau secara tidak langsung karena pertalian perkawinan atau pertalian adat. $^{3}$ Pertalian perkawinan timbul hubungan hukum antara suami isteri dengan anak-anak dan harta

\footnotetext{
${ }^{3}$ Hilman Hadikusuma; 2003; Pengantar Ilmu Hukum Adat Indonesia; Mandar Maju; Bandung., hlm 108.
} 
perkawinan, malainkan juga timbulnya hubungan hukum kekerabatan, anatara menantu dan mertua, hubungan periparan dan besanan dan antara kerabat yang dan yang lainnya. Perkawinan adalah salah satu peristiwa yang sangat penting dalam kehidupan masyarakat adat, sebab perkawinan bukan hanya menyangkut kedua mempelai, tetapi juga orang tua kedua belah pihak, saudara-saudaranya, bahkan keluarga mereka masing-masing. Masyarakat adat Lampung yang terbagi dalam Lampung Saibatin dan Pepadun memiliki cara pelaksanaan hukum perkawinannya yang berbeda - beda karena memang dalam adat Lampung pun masih memiliki keberagaman. Begitu pula dengan masyarakat adat Lampung Saibatin yang memiliki hukum adat perkawinan sendiri. Akan tetapi, secara umum seluruh masyarakat adat Lampung memiliki suatu adat atau kebiasaan dalam perkawinan yang sudah ada sejak zaman dahulu yang salah satunya dikenal dengan istilah kawin lari (sebambangan). Latar belakang kawin lari atau Sebambangan ini adalah dikarenakan "cinta kasih" yang melampaui batas, dan atau karena pihak pemuda tidak mampu memenuhi biaya adat perkawinan yang diminta pihak gadis. ${ }^{4}$ Sebambangan merupakan salah satu adat masyarakat Lampung yang masih bertahan sampai

\footnotetext{
4 , hlm. 162.
}

sekarang ini. Sebambangan adalah awal atau cikal bakal terjadinya perkawinan antara gadis yang selanjutnya disebut $m u l i^{5}$ dan bujang yang selanjutnya disebut mekhanai $^{6}$ yang memilik hubungan spesial dengan maksud ingin melangsungkan perkawinan, akan tetapi takut tidak mendapatkan restu dari orangtua serta keluarga dan adanya keinginan untuk mengikuti adat yang ada sehingga melaksanakan proses sebambangan. Sebambangan dilakukan sesuai dengan janji antara muli dan mekhanai, saat sebambangan, muli meninggalkan surat dan uang peninggalan atau tengepik dengan jumlah sesuai permintaan dari muli, yang kemudian surat dan tengepik tersebut diletakkan di suatu tempat oleh si muli agar keluarganya dapat menemukan surat dan tengepik tersebut.

\section{Kaitannya Dengan Eksistensi Hukum Adat Dengan Undang- Undang Nomor 1 Tahun 1974 Tentang Perkawinan.}

Akibat hukum dari perkawinan antara suami istri menurut Undang-Undang Nomor 1 Tahun 1974 tentang Perkawinan, telah diatur dengan jelas dan gampang dipahami, ketika adanya niat yang baik dalam menegakkan dan menghormati

\footnotetext{
${ }^{5}$ Muli adalah sebutan anak perempuan dalam bahasa lampung

${ }^{6}$ Mekhanai adalah sebutan anak laki-laki dalam bahasa lampung
} 
UndangUndang. Suatu perkawinan yang dilangsungkan secara sah menurut hukum akan menimbulkan berbagai akibat hukum, yang pada pokoknya ada tiga hal penting yang perlu diperhatikan, yaitu :

\section{Hubungan antara suami istri.}

Berkaitan dengan hubungan antara suami istri dalam Undang-Undang Nomor 1 Tahun 1974 tentang Perkawinan, dalam Pasal 30 sampai dengan Pasal 34 telah dirumuskan secara jelas tentang adanya kedudukan yang seimbang antara suami dan istri, yang masing-masing pihak berhak untuk melakukan perbuatan hukum, baik dalam kehidupan berumah tangga maupun dalam pergaulan hidup bersama dalam

masyarakat. Lebih lengkapnya diuraikan dalam Pasal 31 berbunyi, sebagai berikut :

1. Hak dan kedudukan istri adalah seimbang dengan hak dan kedudukan suami dalam kehidupan rumah tangga dan pergaulan hidup bersama dalam masyarakat.

2. Masing-masing pihak berhak untuk melakukan perbuatan hukum.
3. Suami adalah kepala keluarga dan istri ibu rumah tangga.

Hak dan kedudukan yang seimbang yang diikuti oleh suatu kewajiban yang sama antara suami dan istri dalam membina dan menegakkan rumah tangga yang bahagia dan kekal berdasarkan Ketuhanan Yang Maha Esa akan menjadikan sendi dasar dari susunan masyarakat.

\section{Hubungan orang tua dengan anak sebagai ahli waris dan dengan kekerabatannya.}

Jika dalam perkawinan itu telah dikaruniai keturunan (anak), maka tanggung jawab suami istri akan bertambah pula, dan dengan sendirinya akibat hukum mengenai kedudukan dan hubungan orang tua dengan anakanak telah diatur dalam Bab $\mathrm{X}$ Undang-Undang Nomor 1 Tahun 1974 tentang Perkawinan.

Kewajiban orang tua terhadap anak-anaknya sekaligus sebagai ahli waris dalam perkawinan, diatur dalam Pasal 45, yang berbunyi sebagai brikut :

(1) Kedua orang tua wajib memelihara dan mendidik anak-anak mereka sebaik-baiknya. 
(2) Kewjiban orang tua yang dimaksud dalam ayat (1) pasal ini berlaku sampai anak itu kawin atau dapat berdiri sendiri. Kewajiban mana berlaku terus meskipun perkawinan antara kedua orang tua putus. Sedangkan kewajiban anak-anak terhadap orang tuanya diatur dalam Pasal 46, yaitu:

(1) Anak wajib menghormati orang tua dan mentaati kehendak mereka yang baik.

(2) Jika anak telah dewasa, ia wajib memelihara menurut kemampuannya, orang tua dan keluarga dalam garis lurus ke atas, bila mereka itu memerlukan bantuannya.

Lebih lanjut dalam Pasal 47 mengatur, bahwa :

(1) Anak yang belum mencapai umur 18 (delapan belas) tahun atau belum pernah melagsungkan perkawinan ada di bawah kekuasaan orang tuanya selama mereka tidak dicabut dari kekuasaannya.

(2) Orang tua mewakili anak tersebut mengenai perbuatan hukum di dalam dan diluar Pengadilan.

Tentang hubungan anak dengan kerabat ayah dan ibunya, UndangUndang Nomor 1 Tahun 1974 tentang Perkawinan, mengaturnya dalam dua hal, yaitu :

1. Dalam Pasal 46 ayat (2) tentang kewajiban anak untuk memelihara menurut kemampuannya, orang tua dan keluarga.

2. Dalam Pasal 49 ayat (1) tentang hak keluarga anak dalam garis lurus ke atas yang telah dewasa untuk memohon pencabutan kekuasaan orang tuanya ke Pengadilan.

Akibat hukum pada perkawinan masyarakat hukum adat yaitu tergantung dari sistim kekerabatan yang dianut oleh yang bersangkutan, apakah sistim kekerabatan patrilineal, matrilineal atau parental/bilateral. Dalam perkawinan masyarakat adat, ada tiga hal akibat hukum perkawinan yang ditimbulkannya, yaitu :

\section{a. Hubungan antara suami istri.}


Pada masyarakat yang bersistem kekerabatan patrilineal, dengan diterimanya uang atau barang jujur berarti perempuan tersebut telah mengikatkan dirinya pada perjanjian untuk ikut pihak suami, baik pribadi maupun harta benda yang dibawa, maka akan tunduk pada hukum adat suami, kecuali ada ketentuan lain yang menyangkut barang-barang bawaan istri tertentu.

Hal tersebut di atas seiring dengan yang dinyatakan oleh Hilman Hadikusuma, bahwa :

Setelah istri berada ditangan susmi, maka istri dalam segala perbuatan hukumnya harus berdasarkan persetujuan suami atau atas persetujuan kerabat suami. Istri tidak boleh bertindak sendiri, oleh karena ia adalah pembantu suami dalam mengatur kehidupan berumah tangga, baik dalam hubungan kekerabatan maupun dalam hubungan kemasyarakatan. ${ }^{7}$

Akibat hukum yang terjadi dari sistem ini adalah istri karena perkawinannya (uang jujur) dikeluarkan dari keluarganya kemudian masuk ke dalam keluarga suaminya. Anak-anak yang lahir menjadi keluarga bapak (suami), harta yang ada milik bapak (suami)

\footnotetext{
${ }^{7}$ Hilman Hadikusuma, Op. Cit, hlm. 73.
}

yang nantinya diperuntukkan bagi anak-anak yang menjadi keturunannya. Pada masyarakat yang bersistim kekerabatan matrilineal dengan sistem perkawinan semenda mempunyai akibat hukum, yaitu semua keluarga adalah keluarga ibu, harta yang ada merupakan milik ibu yang nantinya diperuntukan bagi anak-anak keturunannya, sedangkan suami (bapak) tidak masuk dalam keluarga ibu. Sedangkan dalam masyarakat yang bersistem kekerabatan Parental/bilateral adalah karena menganut sistem perkawinan mentas yang bersifat bebas, mempunyai akibat hukum antara kedudukan antara lakilaki dan perempuan tidak dibedakan. Artinya diantara suami dan istri bebas untuk menentukan dimana yang bersangkutan untuk menceburkan diri.

\section{a. Hubungan anak-anak dengan kedua orang tuannya dan dengan kerabat ayah ibunya.}

Dalam masyarakat yang bersistem kekerabatan patrilineal, sebagai konsekwensi dari perkawinan dengan cara pembayaran uang jujur maka semua anak yang lahir dari perkawinan itu masuk dalam klan ayahnya dan anak-anak baik laki-laki maupun perempuan berhak untuk memakai 
marga dari ayahnya. Berikutnya apabila perkawinan orang tuannya putus karena percereian (cerei hidup) maka semua anak harus tetap tinggal bersama ayahnya.

Demikian sebaliknya bahwa konsekwensi masyarakat yang bersistem kekerabatan matrilineal yaitu menyatakan semua anak yang dilahirkan dari perkawinannya itu adalah milik ibunya. Sehingga apabila terjadi percereian semua anak harus tetap tinggal bersama kerabat ibunya.

Sedangkan pada masyarakat yang bersistem kekerabatan parental/bilateral, semua anak dari hasil perkawinannya adalah milik kedua orang tuannya, sehingga apabila terjadi percereian maka pengurusan dan kedudukan anak dibicarakan secara musyawarah mufakat demi kesejahteraan anak. Peraturan Pemerintah Nomor 9 Tahun 1975 tentang Pelaksanaan Undang-Undang Nomor 1 Tahun 1974 tentang Perkawinan.

\section{Hubunga Hukum Adat dan}

\section{Hukum Harta Perkawinan}

Dalam pasal 1 Undang-Undang Nomor 1 Tahun 1974 tentang Perkawinan dinyatakan bahwa perkawinan adalah ikatan lahir batin antara seorang pria dan seorang wanita sebagai suami isteri dengan tujuan membentuk keluarga (rumah tangga) yang bahagia dan kekal berdasarkan Ketuhanan Yang Maha Esa. Untuk mencapai kebahagiaan tersebut salah satu faktor yang menentukan adalah dibutuhkan suatu kekayaan duniawi guna mencukupi keperluan hidup bersama-sama, yang nantinya akan dipergunakan oleh suami isteri untuk membiayai ongkos kehidupan mereka beserta anakanaknya. Kekayaan duniawi tersebut populer dengan istilah "harta perkawinan".

Salah satu materi hukum adat asli yang dimasukkan dalam Undang-Undang perkawinan adalah pengaturan hukum harta perkawinan. Secara garis besar dalam hukum adat parental, harta perkawinan dibagi menjadi 2 (dua) yaitu harta asal dan harta bersama. $^{8}$ Pengaturan harta perkawinan menurut hukum adat tersebut kemudian dituangkan dalam pasal 35 UndangUndang Perkawinan yang menyatakan bahwa harta benda yang diperoleh selama perkawinan menjadi harta bersama. Pasal tersebut dipertegas lagi

\footnotetext{
${ }^{8}$ Harta bersama adalah harta yang diperoleh selama perkawinan, tanpa melihat siapa yang memperoleh harta tersebut, sedangkan yang disebut sebagai harta asal/bawaan adalah harta yang diperoleh sebelum perkawinan, yang nantinya baik suami atau isteri dapat bertindak sepenuhnya untuk melakukan perbuatan hukum mengenai harta bendanya.
} 
oleh pasal 37 yang menyatakan bahwa bila perkawinan putus karena perceraian, harta bersama diatur menurut hukumnya masingmasing. Karenanya, di dalam praktik di masyarakat, yang dimaksud dengan hukumnya masing-masing dalam membagi harta, salah satunya adalah hukum adat tentang harta perkawinan.

Menurut hukum adat di Indonesia, apabila terjadi perceraian maka harta bersama pada umumnya dibagi antara suami isteri, yang pada umumnya masing-masing menerima setengah bagian. Namun di beberapa daerah mempunyai kebiasaan yang berbeda, misalnya di daerah Lampung memperoleh dua pertiga dan isteri memperoleh sepertiga. Di pulau Bali dikenal asas sasuhun sarembat, yang membagi harta bersama seperti yang berlaku di daerah Lampung tersebut. ${ }^{9}$ Sesudah perang dunia kedua, perkembangan menunjukan bahwa kebiasaan di atas lambat laun tidak berlaku, dengan semakin tumbuhnya keinsyafan atas persamaan hak antara wanita dan pria, sebagaimana keputusan Mahkamah Agung No. 387 K/Sip./1958, tanggal 25 Pebruari 1959, yang menyatakan bahwa di Lampung, seorang janda mendapat separuh dari

\footnotetext{
${ }^{9}$ Wignjodipuro, Pengantar, hlm.158.
}

harta gono-gini. ${ }^{10}$ Perubahan ini merupakan bukti bahwa hukum adat bersifat dinamis, sehingga ketika keadaan suatu masyarakat berubah, maka akan terjadi perubahan juga terhadap hukum adatnya.

\section{Bagaimanakah Penyelesaian kontra adat Sebambangan dimata masyarakat Umum yang menjadi Pro dan Kontra?}

Penyelesaian secara kekeluargaan dan secara adat. Beda halnya kalau ada paksaan," terang Rusdi, Juma. Dalam adat Lampung, Rusdi mengatakan, memang berlaku adat kawin lari yang telah berlangsung secara turuntemurun. "Tapi kembali lagi ke tata cara itu. Ada syarat-syarat tertentu yang harus dipenuhi. Misalnya ada uang tali pengendur dan surat tenepik," dan pembayaran uang jujur yang menjadi salah satu syarat sebambangan dalam adat Lampung.

2.

\section{Adat Dalam Sebambangan}

\section{F. Konsep Perkawinan Adat Lampung Saibatin}

Adat perkawinan adalah merupakan upacara perkawinan menurut tata cara

${ }^{10}$ Ibid. 
aturan adat tertentu. Mulanya perkawinan secara adat bagi orang Lampung baik itu jurai pepadun maupun saibatin, keduanya menggunakan pola perkawinan bujujogh.

Bujujogh merupakan suatu cara pelaksanaan perkawinan, yang juga menentuakn status perkawinan itu sendiri yakni perempuan mengikuti laki-laki sampai akhir hayatnya dengan kata lain pihak lelaki yang menentukan garis keturunan

(patrilinear). Akan tetapi, khususnya pada suku Lampung Saibatin, adat perkawinan tidak hanya dilakukan secara bujujogh tetapi juga dengan cara semanda. Perkawinan semanda merupakan cara perkawinan yang diadopsi dari adat Minangkabau, dimana segala sesuatu dihitung dari garis keturunan ibu atau wanita Perkawinan semanda dilakukan hanya apabila sebuah keluarga tidak memiliki anak laki-laki.

Adat perkawinan Lampung baik Pepadun maupun Saibatin dalam menyelenggarakan pesta adat perkawinan dapat menyelenggarakan pesta yang megah dan mewah sesuai dengan norma dan nilai adat Lampung, maupun secara sederhana. "bentuk upacara perkawinan adatnya bermacam-macam dan bertingkattingkat, yang di zaman dahulu berdasarkan tingkat kepunyimbangan.
Namun dimasa sekarang telah berubah, tergantung pada keinginan, dan kemampuan keluarga yang akan menyelenggarakannya dengan meminta persetujuan kepunyimbangan yang ada".

Dalam upacara adat perkawinan Lampung Saibatin ada dua pesta adat, yaitu nayuh balak dan bedu'a di lamban

a. Nayuh balak adalah acara perkawinan besar-besaran yang dilaksanakan tujuh hari tujuh malam dengan menyembelih tujuh ekor kerbau. Pelaksanaan nayuh balak diputuskan pada rapat adat atau prowatin atas permintaan dan usul dari kesepakatan keluarga lakilaki. Rapat ini diadakan sebulan sebelum hari perkawinan.

b. Bedu'a di lamban adalah acara perkawinan adat yang sederhana. Acara dilakukan di dalam rumah sehingga tidak memerlukan tarup. Tradisi adat yang dilaksanakan pun sedikit.

\section{Perkawinan Lari atau}

\section{Sebambangan}

Perkawinan lari sering terjadi pada tatanan garis keturunan ayah pada umumnya dan wilayah-wilayah parental seperti masyarakat adat Lampung, Batak, Bali, Bugis/Makasar, dan Maluku. Meskipun perkawinan lari merupakan pelanggaran adat, akan tetapi dalam lingkungan masyarakat adat tersebut terdapat tata- 
tertib

cara

menyelesaikannya.

Sesungguhnya perkawinan lari bukanlah bentuk perkawinan melainkan merupakan sistem pelamaran. ${ }^{11}$ Oleh karena dari kejadian perkawinan lari itu dapat berlaku bentuk perkawinan jujur, semanda atau bebas (mandiri), tergantung pada keadaan dan perundingan kedua pihak. Sistem perkawinan lari dapat dibedakan antara perkawinan lari bersama dan perkawinan lari paksaan. Perkawinan lari bersama yang dalam bahasa Belanda disebut dengan istilah vlucht-huwelijk, wegloopluwelijk, Batak : mangalawa, Sumatera Selatan : belarian, Bengkulu : selarian, Lampung : Sebambangan, metudau, nakat, cakak lakei, Bali : ngerorod, merangkat, Bugis : silariang, Ambon : lari bini ${ }^{12}$ yaitu perbuatan berlarian untuk melaksanakan perkawinan atas persetujuan si muli. Cara melakukan berlarian tersebut ialah bujang muli sepakat melakukan kawin lari dan pada waktu yang sudah ditentukan melakukan lari bersama, atau si muli secara diam-diam diambil kerabat pihak bujang dari tempat kediamannya, atau si muli datang sendiri ke tempat kediaman pihak bujang yang segala sesuatunya berjalan menurut tata-tertib adat berlarian. Akan tetapi, pada masyarakat adat Lampung sangat jarang terjadi seorang

\footnotetext{
${ }^{11}$ Hilman Hadikusuma, Pengantar Ilmu Hukum Adat Indonesia, Op.Cit., hlm. 189

${ }^{12}$ Hilman Hadikusuma, Op.Cit., hlm. 189-190.
}

muli yang datang sendiri ke rumah pria, jika hal tersebut terjadi maka terdapat keadaan yang tidak baik bagi si muli (hamil di luar perkawinan yang sah). Pada dasarnya perkawinan lari terjadi atas kesepakatan antara bujang dan muli, akan tetapi terdapat pengecualian bagi perkawinan lari paksaan (Belanda : Schaak-huwelijk, Lampung

Dibembangkan, ditekep, ditenggang, ditunggang, Bali : Melegandang) adalah perbuatan melarikan muli dengan akal tipu, atau dengan paksaan atau kekerasan, tidak atas persetujuan si muli dan tidak menurut tata tertib adat berlarian. ${ }^{13}$

\section{PENUTUP}

\section{A. Kesimpulan}

Berdasarkan uraian dari hasil penelitian dan pembahasan pada bab-bab sebelumnya, maka dapat ditarik kesimpulan sebagai berikut:

1. Sebambangan merupakan tradisi adat masyarakat Lampung yang disebabkan oleh beberapa alasan, yaitu meliputi internal dan eksternal. Internal meliputi suka sama suka, pendidikan, faktor usia atau umur. Sedangkan eksternal meliputi alasan ekonomi, restu orang tua, menghindari biaya yang besar, alasan sosial dan

\footnotetext{
${ }^{13}$ Hilman Hadikusuma, Pengantar Ilmu Hukum Adat Indonesia Edisi Revisi, Mandar Maju, Bandung, 2014, hlm. 183.
} 
keterpaksaan. Semua alasan melakukan

sebambangan

diselesaikan melalui caranya masingmasing. Berdasarkan tabel nya, alasan suka sama sama suka yang menjadi alasan utama muli dan menkhanai melakukan sebambangan di Kabupaten Tulang Bawang.

2. Akibat hukum dari perkawinan antara suami istri menurut Undang-Undang Nomor 1 Tahun 1974 tentang Perkawinan, telah diatur dengan jelas dan gampang dipahami, ketika adanya niat yang baik dalam menegakkan dan menghormati Undang-Undang. Suatu perkawinan yang dilangsungkan secara sah menurut hukum akan menimbulkan berbagai akibat hukum, yang pada pokoknya ada tiga hal penting yang perlu diperhatikan, yaitu : Hubungan antara suami istri, Hubungan orang tua dengan anak sebagai ahli waris dan dengan kekerabatannya, Hubungan anakanak dengan kedua orang tuannya dan dengan kerabat ayah ibuny. Salah satu materi hukum adat asli yang dimasukkan dalam UndangUndang perkawinan adalah pengaturan hukum harta perkawinan. Penyelesaian prodan kontra dalam masyarakat dilakukan secara kekeluargaan dan secara adat. Beda halnya kalau ada paksaan," terang Rusdi, Juma. Dalam adat Lampung, Rusdi mengatakan, memang berlaku adat kawin lari yang telah berlangsung secara turuntemurun. "Tapi kembali lagi ke tata cara itu. Ada syarat-syarat tertentu yang harus dipenuhi. Misalnya ada uang tali pengendur dan surat tenepik," dan pembayaran uang jujur yang menjadi salah satu syarat sebambangan dalam adat Lampung.

\section{B. Saran}

Berdasarkan uraian diatas, maka penulis memiliki beberapa saran yang ditujukan kepada beberapa pihak, yaitu :

Tokoh adat, yaitu agar tetap berpegang teguh kepada pedoman hukum adat dalam menyelesaikan permasalahan sebambangan sertat membuat peraturan adat yang mengatur mengenai penyelesaian sebambangan maupun proses menuju perkawinan agar penyelesaian sesuai dengan ketentuan yang ada. Masyarakat Adat Lampung yaitu generasi muda agar dapat melestarikan dan mempertahankan adat istiadat budaya khusunya adat Lampung supaya tidak punah 


\section{Daftar Pustaka}

\section{A. Buku}

Hilman Hadikusuma, Pengantar Ilmu Hukum Adat Indonesia, Op.Cit., hlm. 189

Hilman Hadikusuma, Op.Cit., hlm. 189190.

Hilman Hadikusuma, Op. Cit, hlm. 73.

Hilman Hadikusuma, Pengantar Ilmu Hukum Adat Indonesia Edisi Revisi, Mandar Maju, Bandung, 2014, hlm. 183.

Hilman Hadikusuma; 2003; Pengantar Ilmu Hukum Adat Indonesia; Mandar Maju; Bandung., hlm 108.

Pernikahan Adat Lampung, Gramedia, 2015, hlm 42

Rahmat Budi Nuryadin, Tinjauan Hukum Islam Terhadap Prosesi Sebambangan Dalam

Universitas Islam Negeri Sunan Kalijaga, Yogyakarta, 2013, hlm 21

Sudarsono, Hukum Perkawinan Nasional, Rineka Cipta, Jakarta, 1991, hlm 9

Soedharyo Soimin, Hukum Orang dan Keluarga Edisi Revisi, Sinar Grafika, 2001, hlm 6

Wignjodipuro Harta bersama, Pengantar, hlm. 158 .

\section{B. Undang-Undang}

Undang-Undang Nomor 1 Tahun 1974 Tentang Perkawinan

\section{Lain-Lain}

Pemerintah Prop. Lampung, Dinas Pendidikan dan Kebuadayaan Bagian Proyek Pengembangan Masyarakat Bidang Pendidikan Lampung, Bunga Rampai Upacara Adat Lampung, Tahun 2001. Dan Zainal Arzahid, Sa'id Har, Tokoh Adat Lampung, pada tanggal 22-23 September 2008. 